\title{
Pengaruh Kinerja Keuangan Terhadap Return Saham Pada Beberapa Industri Manufaktur yang Terdaftar di Bursa Efek Indonesia
}

\author{
Kurniaty $^{1}$, Aris Setia Noor ${ }^{2}$ \\ ${ }^{12}$ Universitas Islam Kalimantan Muhammad Arsyad Al-Banjari \\ Email : kurniaty.uniska@gmail.com
}

\begin{abstract}
This study aims to determine the effect of financial performance on stock returns in the manufacturing companies in the consumer goods industry sector which are listed on the Indonesia Stock Exchange from 2014 to 2016 simultaneously or partially. The variables used in this study are Return On Assets (X1), Return On Equity (X2), Economic Value Added (X3) as the independent variable and Stock return as the dependent variable.

Samples were taken as many as 20 manufacturing industry companies listed on the Indonesia Stock Exchange (IDX) during 2014 to 2016. The data used are financial reports from each sample company which are published on the website ww.idx.co.id. the data analysis method used in this study is a quantitative method by testing classic assumptions, and statistical analysis is multiple linear regression analysis. The sampling method used was purposive sampling.
\end{abstract}

Keywords: Return On Assets, Return On Equity, Economic Value Added and Stock Return.

Abstrak

Penelitian ini bertujuan untuk mengetahui pengaruh kinerja keuangan terhadap return saham pada perusahaan manufaktur sektor industri barang konsumsi yang terdaftar di Bursa Efek Indonesia sejak tahun 2014 sampai dengan 2016 secara serempak maupun parsial. Variabel yang digunakan dalam penelitian ini adalah Return On Asset $\left(\mathrm{X}_{1}\right)$, Return On Equity $\left(\mathrm{X}_{2}\right)$, Economic Value Added $\left(\mathrm{X}_{3}\right)$ sebagai variabel independen dan Return saham sebagai variabel dependen.

Sampel yang diambil sebanyak 20 perusahaan industry manufaktur yang terdaftar di Bursa Efek Indonesia (BEI) selama tahun 2014 sampai 2016. Data yang digunakan adalah laporan keuangan dari masing-masing perusahaan sampel yang dipublikasikan melalui website ww.idx.co.id. metode analisis data yang digunakan dalam penelitian ini adalah metode kuantitatif dengan pengujian asumsi klasik, serta analisis statistik yaitu analisis regresi linear berganda. Metode pengambilan sampel yang digunakan adalah purposive sampling.

Kata Kunci : Return On Assets, Return On Equity, Economic Value Added dan Return saham

(C) 2020 Jurnal Riset Inspirasi Manajemen dan Kewirausahaan

\section{PENDAHULUAN}

Saham adalah salah satu aset yang diperdagangkan oleh perusahaan dalam pasar modal. Pasar modal merupakan salah satu fasilitas untuk menyalurkan dana dari pihak yang memiliki kelebihan dana kepada pihak yang membutuhkan dana. Dengan melonjaknya jumlah saham yang ditransaksikan, dan semakin tingginya volume perdagangan saham, akan dapat mendorong perkembangan pasar modal di Indonesia. Seiring dengan perkembangan tersebut, maka kebutuhan akan informasi dalam pengambilan keputusan investasi di pasar modal juga meningkat.

Untuk itu, investor harus mempertimbangkan kinerja perusahaan tersebut dalam pengambilan keputusan investasi. Informasi yang berhubungan dengan kinerja atau kondisi perusahaan umumnya ditunjukkan dalam laporan keuangan. Laporan keuangan menyediakan informasi keuangan perusahaan, hal ini sebagaimana dalam standar akuntansi keuangan (SAK) menyatakan bahwa tujuan laporan keuangan adalah menyediakan informasi yang menyangkut posisi keuangan, kinerja, serta perubahan posisi keuangan suatu perusahaan yang bermanfaat bagi sejumlah besar pengguna dalam 
pengambilan keputusan ekonomi.

Untuk mengukur kinerja suatu perusahaan, investor biasanya melihat kinerja keuangan yang tercermin dari berbagai macam rasio. Salah satu indikator pengkuran kinerja keuangan yang sering digunakan adalah profitabilitas perusahaan. Alat ukur profitabilitas perusahaan yang sering, digunakan adalah Return On Assets (ROA), dan Return On Equity (ROE). ROA menggambarkan kemampuan asset-asset yang dimiliki perusahaan bisa menghasilkan laba, ROE menggambarkan sejauhmana kemampuan perusahaan menghasilkan laba yang bisa diperoleh pemegang saham. ROE mengukur kemampuan perusahaan dalam memperoleh return bagi investasi yang dilakukan oleh investor, menunjukkan seberapa besar keuntungan yang menjadi hak pemegang saham (Brigham dan Houston, 2010;36).

Meskipun telah digunakan secara luas oleh investor sebagai salah satu dasar dalam pengambilan keputusan investasi karena nilainya tercantum dalam laporan keuangan, penggunaan analisis rasio keuangan sebagai alat pengukur akuntansi konvensional memiliki kelemahan utama, yaitu mengabaikan adanya biaya modal sehingga sulit untuk mengetahui apakah suatu perusahaan telah berhasil menciptakan suatu nilai atau tidak. Untuk mengatasi kelemahan tersebut, digunakan economic value added (EVA) yang mencoba mengukur nilai tambah (value creation) yang dihasilkan suatu perusahaan dengan cara mengurangi laba operasi setelah pajak dengan beban biaya modal (cost of capital), dimana beban biaya modal mencerminkan tingkat resiko perusahaan yang timbul sebagai akibat investasi yang dilakukan.

Penggunaan metode EVA membuat perusahaan lebih memfokuskan perhatian pada usaha penciptaan nilai perusahaan. Pengertian nilai diartikan sebagai nilai daya guna maupun benefit yang dinikmati oleh stakeholder ( karyawan. investor, pemilik, dan pelanggan). Metode ini relatif sulit diterapkan karena memerlukan perhitungan atas biaya yang kompleks. Namun bagi perusahaan yang listed di pasar modal mungkin akan lebih mudah menghitungnya, daripada perusahaan yang belum go publik di pasar modal.

EVA yang positif menandakan perusahaan berhasil menciptakan nilai bagi pemilik modal, karena perusahaan mampu menghasilkan tingkat pengembalian yang melebihi tingkat biaya modal. Namun EVA yang negative akan menurunkan nilai perusahaan.

Pada hakikatnya, seorang investor melakukan investasi dengan harapan untuk investasinya tersebut mampu memberikan tingkat pengembalian ( rate of return) yang diharapkan. Investasi di bursa efek merupakan jenis investasi dengan resiko relatif tinggi meskipun menjanjikan keuntungan yang relatif besar.

Tingkat keuntungan (return) merupakan rasio antara pendapatan investasi selama beberapa periode dengan jumlah dana yang diinvestasikan. Pada umumnya investor mengharapkan keuntungan yang tinggi dengan resiko kerugian yang sekecil mungkin, sehingga para investor berusaha menentukan tingkat keuntungan investasi yang optimal dengan menentukan konsep investasi yang memadai. Konsep ini penting karena tingkat keuntungan yang diharapkan dapat diukur. Dalam hal ini tingkat keuntungan dihitung berdasarkan selisih antara capital gain dan capital loss. Rata-rata return saham biasanya dihitung dengan mengurangkan harga saham periode tertentu dengan harga saham periode sebelumnya dibagi dengan harga saham sebelumnya.

\section{KAJIAN LITERATUR}

Kinerja perusahaan adalah suatu tampilan tentang kondisi finansial perusahaan selama periode waktu tertentu. Untuk mengukur keberhasilan suatu perusahaan pada umumnya berfokus pada laporan keuangan disamping data-data non keuangan lain yang bersifat sebagai penunjang. Penilaian kinerja menurut Mulyadi (2007) adalah

Penentuan secara periodik tampilan perusahaan yang berupa kegiatan operasional, struktur organisasi dan karyawan berdasarkan sasaran, standar, dan kriteria yang telah ditetapkan sebelumnya.

Penilaian kinerja ini sangat penting bagi proses merger perusahaan, restrukturisasi pengimplementasian program pemulihan usaha, dan untuk menentukan nilai wajar saham yang akan ditawarkan di bursa. Kinerja perusahaan dapat diukur dari laporan keuangan berupa neraca, laba rugi, arus kas dan perubahan modal yang secara bersama-sama memberikan suatu gambaran tentang posisi keuangan perusahaan yang dikeluarkan secara periodik.

Manfaat penilaian kinerja yaitu sebagai berikut:

1. Mengelola operasi organisasi secara efektif dan efisien melalui pemortivasian karyawan secara maksimum.

2. Membantu pengambilan keputusan yang bersangkutan dengan karyawan seperti: promosi, transfer, dan pemberhentian

3. Mengidentifikasi kebutuhan pelatihan dan pengembangan karyawan dan untuk 
menyediakan kriteria seleksi dan evaluasi program pelatihan karyawan.

4. Menyediakan umpan batik bagi karyawan mengenai bagaimana atasan mereka menilai kinerja mereka.

5. Menyediakan suatu dasar bagi distribusi penghargaan.

\section{Rasio Keuangan}

Salah satu cara untuk menilai kinerja keuangan perusahaan adalah dengan menggunakan analisis rasio keuangan. Melalui rasio-rasio keuangan tersebut, pemakai informasi keuangan akan dapat mengetahui kondisi suatu perusahaan.

Dengan menganalisis kinerja keuangan, investor maupun calon investor dapat menilai apakah manajer dapat merencanakan dan mengimplementasikan setiap tindakan secara konsisten dengan tujuan memaksimumkan kemakmuran pemegang saham.

Analisis rasio keuangan dapat dikelompokkan menjadi 5 jenis berdasarkan ruang lingkupnya, yaitu: (Ang, 2007)

1. Rasio likuiditas

Rasio ini menyatakan kemampuan perusahaan untuk memenuhi kewajibannya dalam jangka pendek. Rasio likuiditas terdiri dari: current ratio, quick ratio, dan net working capital.

2. Rasio solvabilitas

Rasio ini menunjukkan kemampuan perusahaan dalam memenuhi kewajiban jangka panjang. Rasio solvabilitas terdiri dari: debt ratio, debt to equity ratio, long term debt to equity ratio, long term debt to capitalization ratio, times interest earned, cash flow interest coverage, cash flow interest coverage, cash flow to net income, dan cash return on sales.

3. Rasio aktivitas

Rasio ini menunjukkan kemampuan perusahaan dalam memanfaatkan harta yang dimilikinya. Rasio aktivitas terdiri dari: total asset turnover, fixed asset turnover, account receivable turnover, inventory turnover, average collection period, dan day's sales in inventory.

4. Rasio rentabilitas/profitabilitas

Rasio ini menunjukkan kemampuan dari perusahaan dalam menghasilkan keuntungan. Rasio rentabilitas terdiri dari: gross profit margin, net profit margin, return on assets, return on equity, dan operating ratio.

5. Rasio pasar

Rasio ini menunjukkan informasi penting perusahaan dan diungkapkan dalam basis per saham. Rasio pasar terdiri dari: dividend yield, dividend per share, dividend payout ratio, price earning ratio, earning per share, book value per share, dan price to book value.

\section{Return on Asset (ROA)}

Pengukuran kinerja keuangan perusahaan dengan ROA menunjukkan kemampuan atas modal yang diinvestasikan dalam keseluruhan aktiva yang dimiliki untuk menghasilkan laba. ROA (Return On Asset) adalah rasio keuntungan bersih setelah pajak untuk menilai seberapa besar tingkat pengembalian dari asset yang dimiliki oleh perusahaan. ROA yang negatif disebabkan laba perusahaan dalam kondisi negatif pula atau rugi. Hal ini menunjukkan kemampuan dari modal yang diinvestasikan secara keseluruhan belum mampu untuk menghasilkan laba.

Keunggulan ROA diantaranya adalah sebagai berikut:

1. ROA merupakan pengukuran yang komprehensif dimana seluruhnya mempengaruhi laporan keuangan yang tercermin dari rasio ini.

2. ROA mudah dihitung, dipahami, dan sangat berarti dalam nilai absolut.

3. ROA menipakan denominator yang dapat diterapkan pada setiap unit organisasi yang bertanggung jawab terhadap profitabilitas dan unit usaha.

Disamping beberapa keunggulan diatas ROA juga memiliki kelemahan yaitu (Handoko w, 2008):

1. Pengukuran kinerja dengan menggunakan ROA membuat manajer divisi memiliki kecenderungan untuk melewatkan projectproject yang menurunkan divisional ROA, meskipun sebenarnya proyek-proyek tersebut dapat meningkatkan tingkat keuntungan perusahaan secara keseluruhan.

2. Manajemen juga cenderung untuk berfokus pada tujuan jangka pendek dan bukan tujuan jangka panjang.

3. Sebuah project dalam ROA dapat meningkatkan tujuan jangka pendek, tetapi project tersebut mempunyai konsekuensi negatif dalam jangka panjang. Yang berupa pemutusan beberapa tenaga penjualan, pengurangan budget pemasaran, dan pengguaaan bahan baku yang relatif murah sehingga menurunkan kualitas produk dalam jangka panjang.

Secara matematis, roa dapat dirumuskan 
sebagai berikut:

$$
\text { ROA }=\frac{\text { EBIT }}{\text { Total Asset }}
$$

Keterangan:

ROA = Return on Equity

EBIT = Earning Before Interest Tax

\section{Return on Equity (ROE)}

Return on Equity (ROE) merupakan rasio antara laba bersih setelah pajak terhadap penyertaan modal saham sendiri yang berarti juga merupakan ukuran untuk menilai seberapa besar tingkat pengembalian dari saham sendiri yang ditanamkan dalam bisnis yang bersangkutan. Tujuan atama dari kegiatan operasi perusahaan adalah untuk menghasilkan laba yang bermanfaat bagi pemegang saham, dan ukurannya adalah pencapaian angka ROE. Oleh karena itu, ROE yang semakin besar juga akan mencerminkan kemampuan perusahaan untuk memberikan keuntungan yang tinggi bagi pemegang saham. ROE dapat dihitung sebagi berikut:

$$
\text { ROE }=\frac{\text { EAT }}{\text { Ekuitas }}
$$

Keterangan:

$\mathrm{ROE}=$ Return on Equity

EAT $=$ Earning After Tax ( laba bersih setelah pajak )

\section{Economic Value Added (EVA)}

Metode EVA pertama kali dikembangkan oleh Steward \& Stern, seorang analis keuangan dari perusahaan stern steward \& co. Konsep Economic Valve Added ( EVA ) mengukur nilai tambah dengan cara mengurangi biaya modal (cost of capital) yang timbul akibat investasi yang dilakukan oleh perusahaan.

EVA yang positif menandakan perusahaan berhasil menciptakan nilai bagi pemilik modal karena perusahaan mampu menghasilkan tingkat penghasilan melebihi tingkat biaya modal. Hal ini sejalan dengan tujuan untuk memaksimalkan nilai perusahaan. Sebaliknya, EVA yang negative menunjukkan bahwa nilai perusahaan menurun karena tingkat pengembalian rendah daripada biaya modalnya. EVA :
1. Menghitung Net Operating Profit After Tax (NOPAT)

NOPAT (Net Operating Profit After Tax) adalah laba yang diperoleh dari operasi perusahaan setelah dikurangi pajak pengnasilan, tetapi termasuk biaya keuangan (financial cost) dan "non cash bookkeepirg entries" seperti biaya penyusatan.

NOPAT = Operating Income + Interest Income + Equity Income (Income From Subsidiary/Affiliated Companies) + Other Income (Investment) - Other Loss - Income Taxes-Tax Shield on Inter

2. Menghitung Invested Capital

Invested Capital adalah jumlah seluruh pinjaman perusahaan di luar pinjaman Jangka pendek tanpa bunga (non-interest bearing liabilities), seperti hutang dagang, biaya yang masih harus dibayar, hutang pajak, uang muka pelanggan, dan sebagainya.

Terdapat dua pendekatan yang dapat digunakan yaitu:

1. Invested Capital dengan Operating Approach

Invested Capital $=$ Kas + Working Capital

Requirement + Aktiva Tetap Dimana:

Rumus Working Capital Requirement (WCR)

$\mathrm{WCR}=($ Persediaan + Piutang Dagang + Aktiva Lancar Lainnya) - (Hutang Dagang + Biaya-Biaya Masih Harus Dibayar + Uang Muka Pelanggan)

2. Invested Capital dengan Financing Approach Invested Capital $=$ Pinjaman Jangka Pendek + Pinjaman Jangka Panjang Lain (Interest Bearing Liabilities) + Ekuitas Pemegang Saham

3. Menghitung Weighted Average Cost of Capital (WACC)

WACC adalah jumlah biaya dari masingmasing komponen modal, misalnya pinjaman jangka pendek dan, pinjaman jangka panjang (cost of debt) serta setoran modal saham (cost of equity) yang diberikan bobot sesuai dengan proporsinya dalam struktur modal perusahaan.

Rumus:

$$
\mathbf{r A}=(\mathrm{D} / \mathrm{V} \times \mathbf{r D})+(\mathrm{E} / \mathrm{V} \times \mathbf{r E})
$$

Keterangan:

$\mathrm{rA}=$ Weighted Average Cost of Capital (WACC)

$\mathrm{D}=\mathrm{Debt}$

$\mathrm{V}=\mathrm{D}+\mathrm{E}$

$\mathrm{rD}=$ Borrowing

$\mathrm{E}=$ Equity 
$\mathrm{rE}=$ Expected Return

4. Menghitung Capital Cost/Charges

- Cost of capital (biaya modal) adalah tingkat pengembalian minimum atas modal yang dibutuhkan untuk mengganti pinjaman dan ekuitas investor. Rumus:

Capital Cost/Charges $=$ Invested Capital $\mathrm{x}$ WACC

5. Menghitung Economic Value Added (EVA) $\mathrm{EVA}=$ NOPAT $-($ Capital $x$ Capital Cost Ratel Cost of Capital) Atau dengan menggunakan EVA $=$ NOPAT $-($ Capital Cost / Charge)

\section{METODE PENELITIAN}

Penelitian ini dilakukan pada lembaga yang berkaitan langsung dengan kegiatan pasar modal yaitu Pusat Informasi Pasar Modal (PIPM) yang merupakan kuasa perwakilan Bursa Efek Indonesia yang berlokasi di Jl. Ahmad Yani, KM 1,5, No. 103, Banjarmasin - Kalimantan Selatan. Telepon. (0511) 325 - 6985. Fax. (0511) 326 - 4079.

\section{Populasi dan Sampel}

Populasi dalam penelitian ini adalah industri manufaktur yang terdaftar di Bursa Efek Indonesia selama tiga tahun berturut-turut, yakni mulai dari tahun 2014-2016. Sampel yang digunakan adalah perusahaan industri manufaktur yang memenuhi kriteria. Sampel dilakukan mengingat adanya kendala, waktu, biaya, serta masalah heterogenitas dari elemen populasi.

Pemilihan sampel dalam penelitian ini menggunakan metode purposive sampling yaitu metode pemilihan sampel yang didasarkan pada kriteria tertentu untuk memperoleh sampel yang representative terhadap populasi. Sampel yang diambil pada industri manufaktur dengan kriteria sebagai berikut:

1. Perusahaan telah terdaftar di Bursa Efek Indonesia (BEI) pada periode penelitian dari tahun 2014-2016

2. Selama periode penelitian, perusahaan membuat laporan tahunan dan dipublikasikan secara luas.

3. Selama periode penelitian, perusahaan membagikan deviden.

\section{HASIL PENELITIAN DAN PEMBAHASAN}

\begin{tabular}{lcrrrr}
\hline \multicolumn{5}{c}{ Descriptive Statistics } \\
\hline & N & Minimum & Maximum & \multicolumn{1}{c}{ Mean } & Deviation \\
\hline Return Saham & 60 & -97.00 & 927.00 & 74.2000 & 171.63568 \\
\hline ROA & 60 & 1.00 & 88.00 & 19.9333 & 16.88231 \\
\hline ROE & 60 & 3.00 & 84.00 & 24.0500 & 16.92198 \\
\hline EVA & 60 & $-6.96 \mathrm{E} 8$ & $-5.08 \mathrm{E} 5$ & $-9.7261 \mathrm{E} 7$ & $1.73201 \mathrm{E8}$ \\
\hline Valid N (listwise) & 60 & & & & \\
\hline
\end{tabular}

Mean dan Standar Deviasi Variabel

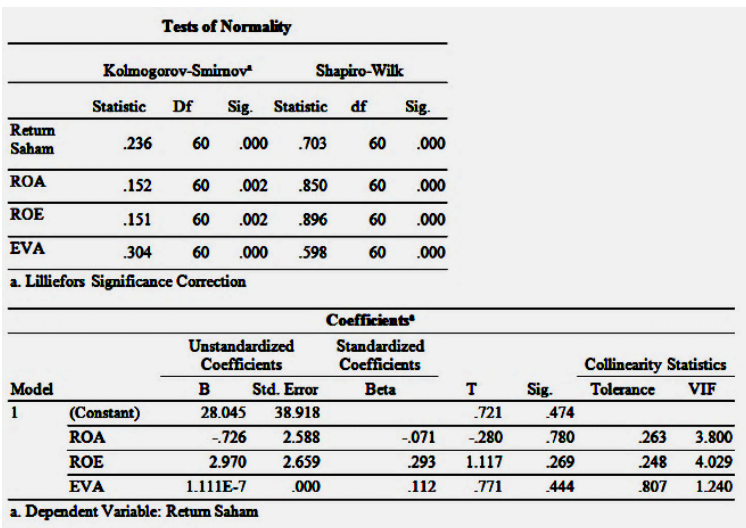

\section{Hasil Hipotesis}

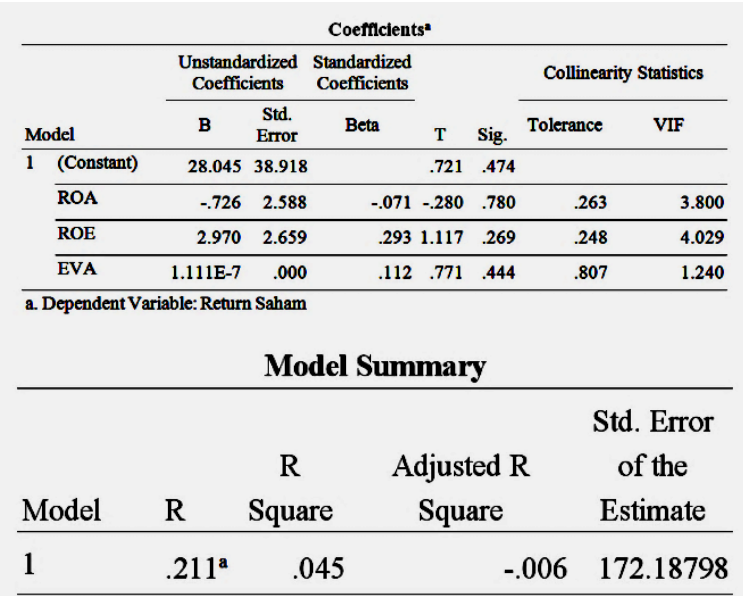

a. Predictors: (Constant), EVA, ROA, ROE

Berdasarkan Hasil Penngujian hipotesis diatas dapat dijelaskan sebagai berikut :

1. Koefisien beta variabel ROA $\left(\mathrm{X}_{1}\right)$ sebesar0.726, dengan tingkat signifikansi 0.780 dan nilai $\mathrm{t}$ hitung $=-0.280$ yang berarti terdapat 
hubungan negatif antara ROA dengan Rate of Return tetapi tidak signifikan karena tingkat signifikansinya $>0.05$ dan $\mathrm{t}$ hitungnya $<\mathrm{t}$ tabel 2,002 yang berarti bahwa menolak hipotesis 1 yang berarti ROA tidak berpengaruh signifikan terhadap return saham.

2. Koefisien beta variabel $\mathrm{ROE}\left(\mathrm{X}_{2}\right)$ sebesar 2.970 dengan tingkat signifikansi 0.269 dan nilai $\mathrm{t}$ hitung $=1.117$ yang berarti terdapat hubungan hubungan negatiff antara ROE dengan Rate of Return tetapi tidak signifikan karena tingkat signifikansinya $>0.05$ dan $\mathrm{t}$ hitungnya $<\mathrm{t}$ tabel 2,002 yang berarti bahwa menolak hipotesis 2 yang berarti ROE tidak berpengaruh signifikan terhadap return saham

3. Koefisien beta variabel EVA $\left(\mathrm{X}_{3}\right)$ sebesar 1.111E7 dengan tingkat signifikansi 0.444 dan nilai $t$ hitung $=0.771$ yang berarti terdapat hubungan hubungan positif antara ROA dengan Rate of Return tetapi tidak signifikan karena tingkat signifikansinya $>0.05$ dan $\mathrm{t}$ hitungnya $<\mathrm{t}$ tabel 2,002 yang berarti bahwa menolak hipotesis 3 yang berarti EVA tidak berpengaruh signifikan terhadap return saham. Nilai adjusted $\mathrm{r}$ square sebesar -0.006 yang dalam hal ini berarti terjadi hubungan yang sangat rendah antara variabel ROA, ROE, dan EVA dengan Return Saham (ROR).

\section{PENUTUP}

ROA, ROE, dan EVA tidak berpengaruh signifikan terhadap Return Saham pada industri manufaktur yang terdaftar di Bursa Efek Indonesia. Hal ini terjadi karena ternyata laba perusahaan yang menjadi salah satu indikator perhitungan ROA, ROE dan EVA bukanlah satu-satunya indikator dalam pengambilan keputusan harga saham. Biaya modal yang menjadi komponen perhitungan EVA sangat dipengaruhi oleh tingkat suku bunga. Selain itu, perbedaan teknis perhitungan, ukuran perusahaan, kondisi pasar uang Indonesia, adanya faktor internal selain fundamental ekonomi, suku bunga, devaluasi, pertumbuhan ekonomi, pengeluaran pemerintah dan jumlah uang beredar, penjualan, pertumbuhan penjualan, biaya, dividen tunai, kondisi sosial, politik dan ekonomi merupakan faktor-faktor yang harus diperhatikan dalam menentukan return saham.

\section{SARAN}

1. Tingkat pengembalian saham (Rate of Return) tidak dipengaruhi oleh ROA, ROE dan EVA yang merupakan ukuran kinerja keuangan suatu perusahaan. Oleh karena itu untuk memperoleh investor yang memadai dengan tingkat pengembalian saham yang tinggi maka perusahaan perlu meningkatkan kinerja keuangan terutama dengan cara mempertimbangkan biaya modal karena menjadi pertimbangan untuk memaksimumkan nilai perusahaan dan agar dapat mengambil keputusan yang tepat berinvestasi.

2. Bagi penelitian berikutnya diharapkan menambah rasio keuangan lainnya sebagai variabel independen, karena sangat dimungkinkan rasio keuangan lain yang tidak dimasukkan dalam penelitian ini berpengaruh terhadap Return Saham.

\section{DAFTAR PUSTAKA}

Ang, Robert. 2007. Buku Pintar: Pasar Modal Indonesia (The Intelligent Guide Indonesia Capital Market). Mediasoft Indonesia, First Edition.

Anoraga, Pandji. 2002. Pengantar Pasar Modal. Jakarta. Rineka Cipta

Brigham dan Houston. 2010. Dasar-Dasar Manajemen Keuangan Buku l.Jakarta: Salemba Empat.

Fandi kurniawan. 2006. Analisis Rasio Likuiditas Sebagai Alat Pengukuran Kinerja Pada PT. Bank Republik Indonesia Tbk. Skripsi. Jurusan Manajemen. FE-UH

Handoko, W, 2008, Pengaruh EVA, ROE, ROA dan EPS Terhadap Perubahan Harga Saham Perusahaan Kategori LQ 45 pada Bursa Efek Indonesia, Skripsi, Fakultas Ekonomi Universitas Muhammadiyah, Surakarta.

Jogiyanto. 2008. Teori Portofolio Dan Analisis. Edisi kelima. Yogyakarta. BPFEYogyakarta

Taufik. Jurnal Kajian Capital Market dan Leverage terhadap Variasi Harga Saham di Bursa Efek Jakarta. Vol 1 
Jurnal Riset Inspirasi Manajemen dan Kewirausahaan Volume 4 No. 2 Edisi September 2020

ISSN: 2549-3477 e-ISSN: 2623-1077 DOI : https://doi.org/10.35130/rimk

https://ejurnal.stimi-bim.ac.id/index.php/JRIMK

Mariana, Sri Rahayu. 2007. Analisis Pengaruh Eva Dan Mva Terhadap Return Saham Pada Perusahaan Manufaktur Di Bursa Efek Jakarta. Skripsi. Jurusan akuntansi. UIIYogyakarta.

Mulyadi, 2007, "Balanced Scorecard," Salemba Empat, Jakarta.

Munawir. S. 2002. Analisis Informasi Keuangan. Yogyakarta. Liberty Yogyakarta

Noer Sasongko. 2003. Pengaruh EVA dan RasioRasio Profitabilitas terhadap Harga Saham. Universitas Muhammadiyah Surakarta.

Priyatno, Dwi. 2008. Mandiri Belajar SPSS (Statistical Product And Service Solution) Untuk Analisis Data \& Uji Statistik. Jakarta. Mediakom

Rahman Hakim. 2006. Perbandingan Kinerja Keuangan Perusahaan dengan Metode EVA, ROA, dan Pengaruhnya terhadap Return Saham pada Perusahaan yang Tergabung dalam Indeks LQ 45 di Bursa Efek Jakarta. Universitas Islam Indonesia. Yogyakarta
Robert n. Anthony \& vijay govindarajan, penerjemah F.X. kurniawan tjakrawala. 2005. Sistem Pengendalan Manajemen. Edisi sebelas. Jakarta. Salemba Empat

Tunggal, Amin Widjaja. 2008. Memahami Economic Value Added. Jakarta. Harvindo www.idx.co.id

\section{Profil Penulis}

1. Dr. Dra. Hj. Kurniaty, M.M., Fakultas Ekonomi, Keilmuan Manajemen, Universitas Islam Kalimantan Muhammad Arsyad AlBanjari (UNISKA MAB) Banjarmasin, Jl. Adhyaksa No.2 Kayutangi 70123

Email : kurniaty.uniska@gmail.com

2. Aris Setia Noor, S.E.,M.Si, Fakultas Ekonomi, Keilmuan Manajemen, Universitas Islam Kalimantan Muhammad Arsyad AlBanjari (UNISKA MAB) Banjarmasin, Jl. Adhyaksa No.2 Kayutangi 70123 Email : arissetianoor@gmail.com 